\title{
Climate Strategy for Producer Countries: The Case of Saudi Arabia
}

\author{
Jim Krane
}

\section{INTRODUCTION}

The simultaneous collapse of oil production and social stability in Venezuela has provided a vivid preview of a potential pathway for oilexport states deprived of hydrocarbon rents to fund their national budgets.

While Venezuela's predicament in 2019 was based on domestic policymaking, some observers suspect that climate action could provoke similar results, leaving oil exporting states with insufficient revenues to maintain public order (Van de Graaf and Verbruggen 2014, 2015, 456-62; Van de Graaf 2018, 97-121).

The notion of an encroaching threat to hydrocarbon demand and rents-as opposed to the debunked "peak oil supply" conundrum of the prior decade-is leading policymakers to reassess long term assumptions about the oil business in two ways: by promoting diversification into alternate businesses, and by protecting and enhancing the competitiveness of their oil industries.

J. Krane $(\bowtie)$

Rice University's Baker Institute for Public Policy, Houston, TX, USA

e-mail: jkrane@rice.edu

(C) The Author(s) 2021

301

G. Luciani, T. Moerenhout (eds.), When Can Oil Economies Be

Deemed Sustainable?, The Political Economy of the Middle East, https://doi.org/10.1007/978-981-15-5728-6_12 
The two strategies appear compatible. The first prepares the economic landscape for a day when oil rents no longer dominate the state's fiscal revenue, whether from a plateauing of global oil demand or any other reason. The second seeks to insulate flows of oil and gas rents against the more direct challenges emanating from climate policy.

Saudi Arabia, the global oil market's largest supplier, has taken steps in both directions. Its initiatives toward diversification are well known and covered elsewhere. ${ }^{1}$ This chapter looks at the other, less explored climate strategy: near-term actions that the kingdom and other producer states have taken or may take in the next few years to maintain oil exports amid the emergence of restrictions on fossil fuels.

Some of the strategies that Saudi Arabia has developed are altering the nature of its participation in the oil business. From simply supplying energy commodities, the kingdom is increasing its involvement in importing markets and in bolstering oil-consuming technology.

One strategy involves investment into refining and other infrastructure ties with developing states where expectations for growth in oil demand are high. A related effort emphasizes low-emission and non-combustion uses for crude oil, which are consistent with a transitioning energy system. Another has the kingdom increasing cooperation with the global climate regime, pursuing a commitment to energy efficiency which does double duty in domestic oil demand management. Yet another strategy seeks to lobby the international community to moderate its targets for greenhouse gas emissions, and accept a higher level of human climate damage.

While this chapter applies these strategies to Saudi Arabia, other producer countries should be expected to take similar steps. The realization that the world is over-endowed with hydrocarbon reserves that may never be produced is forcing a strategic alteration in oil market behavior. Oil and

${ }^{1}$ Sources on the subject are too numerous to cite, but a few bear mentioning: Martin Hvidt, "Economic Diversification in GCC Countries: Past Record and Future Trends," Research Paper, Kuwait Programme series, 2013; Ali Aissaoui, "Saudi Arabia's Economic Diversification: Progress in the Context of the GCC and Challenges," in Resources Blessed: Diversification and the Gulf Development Model, ed. Giacomo Luciani (Berlin: Gerlach Press, 2012), 1-24; Bassam A. Albassam, "Economic Diversification in Saudi Arabia: Myth or Reality?," Resources Policy 44 (2015): 112-17; Tim Callen et al., Economic Diversification in the GCC: Past, Present, and Future (International Monetary Fund, 2014); Giacomo Luciani, "Resources Blessed: Diversification and the Gulf Development Model," in The Gulf Region: Economic Development and Diversification, ed. Giacomo Luciani et al., 4 vols. (Berlin: Gerlach Press, 2012). 
gas markets appear likely to grow more competitive, with producer states vying for market share and differentiating products based on environmental criteria.

What this portends for markets and demand over the longer term is unclear. One envisions the eventual emergence of multiple potential pathways. A cooperative path would see producers collude to manage reductions in production so that prices remain above their cost of extracting the marginal barrel. One can also imagine the emergence of a more hostile dynamic, pitting fossil fuel producers against the efforts of climate-focused states and international organizations. The second pathway might be accompanied by a "green paradox" conundrum, where low-cost producers maintain or even ramp up production, driving down oil prices and helping fossil fuels compete against alternatives. ${ }^{2}$ Given that global carbon dioxide emissions that had fallen from 2014 to 2016 returned to the path of growth in 2017 -rising by $1.6 \%$ that year and again by $2.7 \%$ in 2018 (Jackson et al. 2018) - an intensification of international efforts to discourage fossil fuel use appeared likely.

\section{Contrasting Strategies}

This chapter focuses on three types of nearer-term producer country climate strategies outlined above. Although they sometimes overlap, I have titled them "Dig In," "Join In," and "Throw In."

- DIG IN: Producer governments overtly defend their oil and gas export industries. Their primary concern is not with the direct effects of climate change but indirect effects of climate action on global demand for exportable hydrocarbons, and the socioeconomic damage posed by loss of economic rents. By "digging in," states assume GHG accords such as the 2015 Paris Agreement remain aspirational rather than binding, and act to insulate or harden the hydrocarbon sector against the aims of such accords. Such actions include steps to enhance competition with rival producers and to protect technologies

\footnotetext{
${ }^{2}$ For more detailed discussion of possible oil market reactions to peak demand, see Anupama Sen and Bassam Fattouh, "Economic Diversification in the MENA in the Context of Peak Oil and the Energy Transition," in Workshop on Sustainability in the GCC (Gulf Research Meeting, University of Cambridge, UK, 2018).
} 
linked to continued demand. This includes developing uses for crude oil that remain viable in a climate-constrained market.

- LOCK IN: An important subset of the "Dig In" strategy is the bilateral "Lock In" of markets in key import states through direct investment.

- JOIN IN: Producer governments “join in” to pursue economically rational domestic energy policies that provide secondary benefits in reducing greenhouse gas emissions. The Paris Agreement's Nationally Determined Contributions (NDCs) provide useful political cover for unpopular-albeit environmentally beneficial-actions like Saudi Arabia's reform of energy subsidies. Domestic reforms have the added benefit of freeing up oil and gas that can be exported at market prices.

- THROW IN: The "Throw In" strategy suggests the adage "throw in the towel." Here, elites sympathetic to the interests of producer states and fossil fuel companies concede that climate change is inevitable and argue that damage caused by human greenhouse gas emissions is preferable to costly GHG mitigation in line with the Paris goals.

\section{Saudi Arabia's Climate Profile}

How does Saudi Arabia fit within the taxonomy above? Like other large producers of carbon-intensive fossil fuels, Saudi Arabia finds itself at the center of the global climate conundrum, increasingly recognized as major fossil fuel producer, exporter, subsidizer, and consumer. Saudi Arabia also stands to become an early and significant victim of climate change, since its arid geography and harsh summer climate is highly vulnerable to damage (Pal and Eltahir 2016, 197-200).

Saudi Arabia also carries an outsized legacy of GHG emissions, which began in the pre-nationalization era, due to large-scale methane venting that far outweighed its relatively minor emissions of carbon dioxide of the period. While Saudi $\mathrm{CO}_{2}$ emissions have grown nearly 6\% per year, roughly the same rate as its primary energy demand (EDGAR 2017), the kingdom's methane emissions peaked during the 1970s, a period when the 


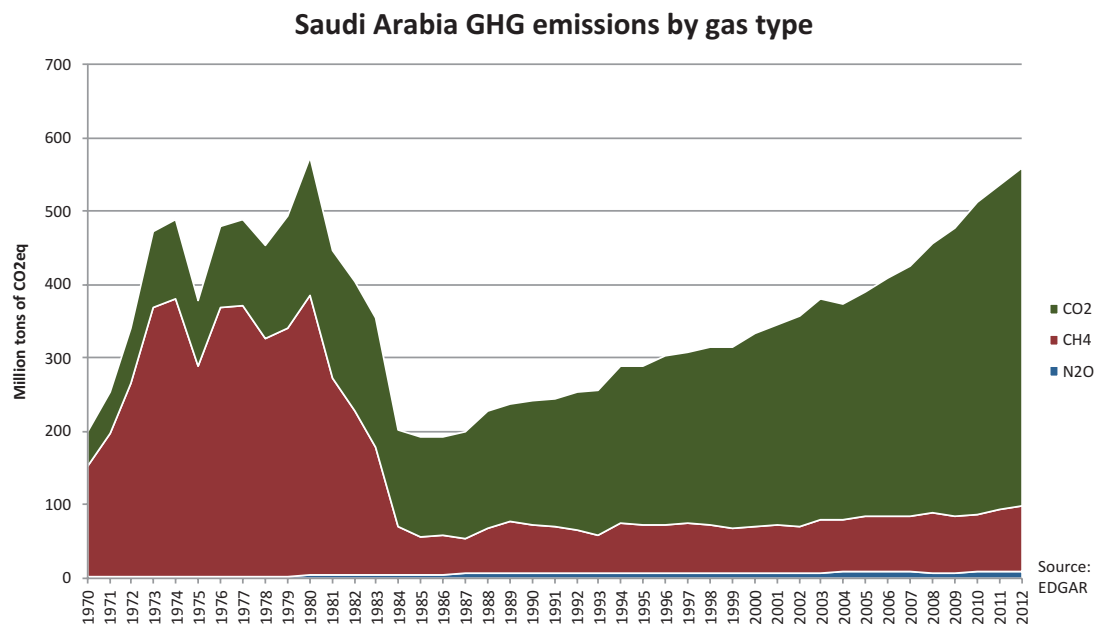

Fig. 12.1 Saudi Arabia GHG emissions by gas type

kingdom's overall GHG emissions reached levels that were only surpassed within the last few years (Fig. 12.1). ${ }^{3}$

At the time, the national oil company, then known as Aramco, was owned and operated by four US companies. After the Saudi government took full control in 1980, GHG emissions dropped as Saudi Aramco built up its Master Gas System based on capturing waste methane and redirecting it to the power sector (Krane 2014). Fugitive (non-combustion) $\mathrm{CO}_{2}$ from the oil industry was another major source of emissions which was curtailed after nationalization, dropping below $50 \%$ of total $\mathrm{CO}_{2}$ emissions by 1979 and reaching $2.2 \%$ in 2008 .

Once upstream fugitive emissions were reduced, the power sector grew to become the kingdom's largest source of carbon dioxide emissions. By 2008 , electricity generation was responsible for $43 \%$ of GHG emitted, followed by transport at $27 \%$ and industry at $17 \%$. Fugitive emissions from the Saudi energy industry totaled $10.5 \mathrm{~m}$ metric tons of $\mathrm{CO}_{2}$ equivalent in

${ }^{3}$ Atmospheric methane has far more potent heat-trapping properties than $\mathrm{CO}_{2}$, but, after a decade or two, its harm is reduced as it decays into $\mathrm{CO}_{2}$. Over a decade, methane warms the planet by 86 times as much as $\mathrm{CO}_{2}$. See: Gayathri Vaidyanathan, "How Bad of a Greenhouse Gas Is Methane?" Scientific American, Dec. 22, 2015. https://www.scientificamerican.com/article/how-bad-of-a-greenhouse-gas-is-methane. 
2008, amounting to just 3\% of the kingdom's entire GHG emissions of $382 \mathrm{~m}$ metric ton (EDGAR 2011).

Today's Saudi emissions flow mainly from Saudi energy consumption. By 2017, Saudi Arabia—the world No. 1 oil exporter-had become the world No. 5 oil consumer, after the United States, China, India, and Japan. It consumed more oil than much larger countries, including Russia, Brazil, or Germany (BP 2018). As such, Saudi Arabia is a leading global emitter of GHGs. The kingdom was the world No. 9 carbon emitter in 2016, according to BP data, ahead of populous oil producers like Brazil, Mexico, and Indonesia, as well as developed states like Canada and Australia, but behind Iran, South Korea, Germany, and Japan. However, $\mathrm{BP}$ data only reflect $\mathrm{CO}_{2}$ emitted from fossil fuel combustion, and ignore other sources. When all GHGs are factored in, Saudi Arabia ranked as the No. 15 emitter in 2012, according to the most recent data collected by the EU's Emissions Database for Global Atmospheric Research (EDGAR). EDGAR GHG data rank the kingdom behind Brazil, Mexico, and Indonesia, as well as Canada and Australia (Table 12.1 and Fig. 12.2).

When compared with its peers in the Gulf Cooperation Council (GCC), Saudi Arabia was the least prolific per-capita emitter, far outpaced by

Table 12.1 Saudi Arabia benchmarked against selected countries in terms of GHGs, population, and economy

\begin{tabular}{lcrccc}
\hline Country & $\begin{array}{c}\text { Crude } \\
\text { NGL export } \\
(\text { KBD })\end{array}$ & $\begin{array}{c}2012 \\
\text { population } \\
\text { (million) }\end{array}$ & $\begin{array}{c}\text { GDP } \\
\text { (US\$ bn } \\
\text { 2011) }\end{array}$ & $\begin{array}{c}\text { 2012 GHG } \\
\text { emissions per } \\
\text { capita (ton of } \\
\text { CO } O_{2} \text { eq) }\end{array}$ & $\begin{array}{c}\text { Average annual } \\
\text { growth rate of } \\
\text { GHG emissions } \\
\text { since } 1970\end{array}$ \\
\hline Australia & 281 & 23 & 967 & 26.4 & $1.70 \%$ \\
UAE & 2625 & 9 & 532 & 25.3 & $2.20 \%$ \\
Canada & 2516 & 35 & 1452 & 20.6 & $1 \%$ \\
USA & 424 & 314 & 15,863 & 19.5 & $0.20 \%$ \\
Saudi & 7442 & 29 & 1444 & 19.2 & $2.50 \%$ \\
Arabia & & & & & \\
Russia & 4858 & 143 & 3602 & 15.9 & $0.60 \%$ \\
Iran & 1371 & 76 & 1271 & 10.3 & $2.50 \%$ \\
Mexico & 1333 & 121 & 1972 & 6 & $2.60 \%$ \\
Brazil & 532 & 200.5 & 3032 & 5.6 & $2.80 \%$ \\
Indonesia & 315 & 249 & 2302 & 3.3 & $3.40 \%$ \\
\hline
\end{tabular}

Source: IEA, World Bank and EDGAR

2012 data (most recent GHG emissions data available) 


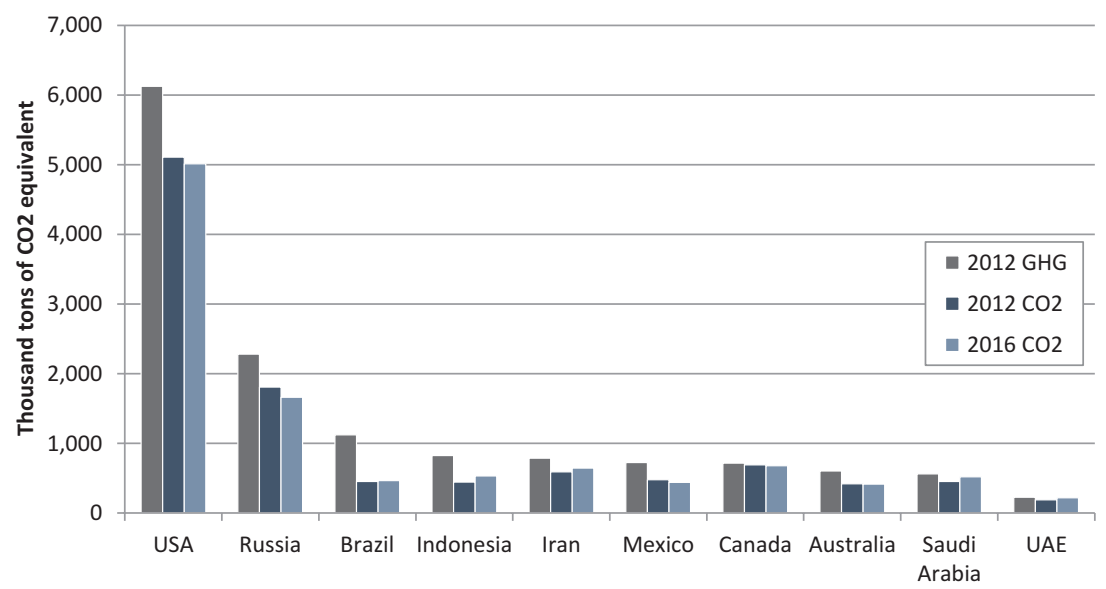

Source:

Fig. 12.2 GHG and $\mathrm{CO}_{2}$ emissions in selected countries

GHG and $\mathrm{CO}_{2}$ emissions per capita in GCC

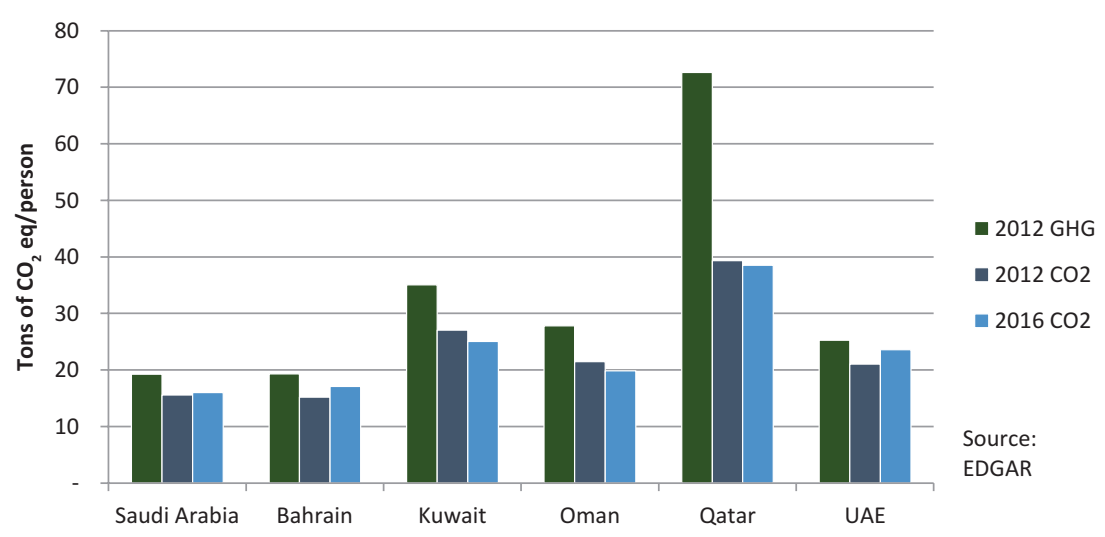

Fig. 12.3 GHG and $\mathrm{CO}_{2}$ emissions per capita in GCC. (Source: EDGAR)

wealthy Qatar and Kuwait, and even ranking behind the United Arab Emirates, Oman, and Bahrain (Fig. 12.3). The high levels of per-capita GHG emissions in the smaller monarchies are partly due to small populations relative to the size of energy-intensive industries. Qatar's natural gas 
sector, including its LNG and gas-to-liquids industries, is a major emitter of both carbon dioxide and fugitive methane. ${ }^{4}$ Other factors include high per-capita incomes, large homes, low electricity prices, and a hot climate that generates demand for indoor cooling (Krane 2015b). Electric power in the residential sector is nearly free in Kuwait, and is free in unlimited quantities for Qatari citizens.

Of course, most of the emissions from Saudi Arabian energy products are tallied in the countries where final combustion takes place. When aggregated, the carbon emitted from Saudi Aramco's oil production has been identified as the world's No. 1 current and No. 2 historical source of GHGs among all commercial fossil fuel companies. Hydrocarbons produced by Saudi Aramco are responsible for about $4.3 \%$ of current global GHG emissions and about $3.2 \%$ of aggregate atmospheric accumulations. ${ }^{5}$ Chevron, the former Standard Oil of California, which discovered oil in Saudi Arabia in 1938 and held the original Saudi concession, is responsible for about $1.2 \%$ of current emissions and $3.5 \%$ of historic emissions, the highest share among historical emitters. ${ }^{6}$

\section{The Importance of Oil in Saudi Political ECONOMY}

The GHG emissions attributed to Saudi Aramco are not only a byproduct of the company's business, but of the commercial activity that underpins the kingdom's economy, its governance structures, and its stature in international relations.

Saudi concerns around climate change center on the reduction or loss of potentially enormous oil rents. The oil sector in Saudi Arabia, like those of other low-cost producers, is extraordinarily profitable. Crude oil that costs less than $\$ 10$ to produce and export sold for $\$ 60$ per barrel at the

${ }^{4}$ Fugitive methane constituted nearly half of Qatar's 2012 GHG emissions, or about 70 of 150 megatonnes of $\mathrm{CO}_{2}$ equivalent, according to EDGAR's dataset. EDGAR, "Fossil $\mathrm{CO}_{2}$ \& GHG Emissions of All World Countries, 2017.”

${ }^{5}$ These figures include flaring and venting of GHGs during production. See: Benoit Mayer and Mikko Rajavuori, "National Fossil Fuel Companies and Climate Change Mitigation under International Law," Syracuse J. Int'l L. \& Com. 44 (2016): 55.

${ }^{6}$ Emissions are from upstream production and final consumption of oil and gas products produced by Chevron. Mayer and Rajavuori. See also: Richard Heede, "Tracing Anthropogenic Carbon Dioxide and Methane Emissions to Fossil Fuel and Cement Producers, 1854-2010," Climatic Change 122, no. 1-2 (2014): 229-41. 
time of writing. Subtracting investment and other costs along with a reasonable rate of return, a substantial portion of the sales revenue-perhaps $80 \%$ - could be described as economic rent. A threat to oil rents thus constitutes a threat to the Saudi government's operating budget and to the nature of tribal-autocratic governance that controls the state.

The profitability of oil also undercuts producers' appetite for diversification. The long term persistence of rents is a nearly unique aspect of the oil business and is partly due to production constraints that maintain high prices. In other sectors, rents are typically driven out over time by new entrants and competition. The durability of rents undermines the already lackluster determination for economic diversification, since it entails acceptance of lower profits and a loss of rents. A thorough diversification might even force the state to augment its income through taxation, undermining the rentier polity.

Finally, carbon extraction and marketing are even of strategic importance for Saudi Arabia, given that oil exports form the basis for the kingdom's geopolitical stature and its important partnership with the United States, which provides hard security for the region. A reduced role in oil markets would weaken Saudi Arabia's external security and downgrade its international standing.

Therefore, Riyadh, like producer governments elsewhere, should be expected to protect an industry so central to the survival of its regime, even to the detriment of the climate affecting its national territory. The following sections describe the shape such actions might take.

\section{Strategy No. 1 "Dig In": Reduce Vulnerability of Oil Sector to Climate Action}

To executives of a national oil company (NOC) such as Saudi Aramco, the default concern about climate change represents qualms around "security of demand" for crude oil within the ongoing clean energy transition (Smith 2010). Securing demand and markets takes several forms.

\subsection{Climate Obstructionism}

In the past, Saudi concern was manifested in an obstructionist stance in international climate fora. Depledge argued that Saudi Arabia joined UN-led climate treaty negotiations because its leadership feared a 
successful agreement and wished to thwart, delay, or weaken it. The kingdom's confrontational stance was based on fears that mitigation policies would harm the kingdom more than the damage of climate change itself (Depledge 2008, 9-35).

Saudi tactics documented by Depledge involved the following:

- Allowing its position to be determined and led by the national petroleum ministry

- Highlighting skeptical views on climate science and downplaying the harmful effects of atmospheric carbon accumulations

- Employing negotiating techniques aimed at postponing or blocking progress

- Aligning with coal lobbies and other interests which oppose climate action

- Using financial incentives to persuade delegations from poorer countries to back the Saudi position.

As the global consensus on climate became more urgent, obstructionist Saudi tactics triggered negative publicity and damaged the kingdom's public image. ${ }^{7}$ During the 2018 UN climate talks in Poland, the Saudi team reprised its obstruction tactics, backed by negotiators from the United States, Russia, and Kuwait. The quartet blocked a measure that would have supported the findings of an Intergovernmental Panel on Climate Change (IPCC) report (Plumer and Friedman 2018). But the kingdom has also turned to a more sophisticated set of strategies to protect its oil business.

\subsection{Petrochemicals and Non-Combustion Uses for Crudes}

First among these is to focus on applications for oil and gas that do not involve burning it. The most important of these "non-combustion uses" is in producing petrochemicals. Demand for petrochemicals has grown more robustly than demand for oil-based fuels ${ }^{8}$ and with higher shareholder

\footnotetext{
${ }^{7}$ See, for example: Jad Mouawad and Andrew C. Revkin, "Saudis Seek Payments for Any Drop in Oil Revenues." New York Times, Oct. 13, 2009; https://www.nytimes. com/2009/10/14/business/energy-environment/14oil.html; and GerardWynn, "U.N. climate talks threaten our survival: Saudi Arabia." Reuters, April 8, 2009.

${ }^{8}$ The IEA in 2018 estimated that petrochemicals formed the fastest-growing demand source for crude oil, with an estimated $25 \%$ of overall growth focused on the sector by 2023 .
} 
returns than other sectors, including, at times, the upstream oil and gas business that provides petrochemical feedstocks (Ezekoye et al. 2018). Attractiveness for investors is augmented by the perceived longevity of the petrochemical business, since petrochemical-based plastics have few substitutes and remain vital to post-transition energy systems. For instance, plastic is crucial for the manufacture of solar panels, wind turbine blades, thermal insulation, batteries, and other components of electric vehicles (IEA 2018).

Thus the conversion of crude oil and natural gas into chemical products comprises perhaps Saudi Aramco's most promising climate hedge. Chemicals represent a growing "climate proof" use for hydrocarbons, through which oil and gas feedstocks are converted into precursor resins and polymers that form the basis for finished products ranging from auto parts to cushions, paint, and toothpaste. The carbon is sequestered in the finished product, rather than released upon combustion, as is the case with gasoline and other fuels.

Saudi-based companies have made major investments in petrochemical plants, both inside the kingdom and outside. Domestic investment includes the \$20 billion Sadara joint venture with Dow Chemical, the largest single-phase chemical plant ever built. Internationally, Saudi Aramco and SABIC, the state-held petrochemical giant, have proposed joint venture projects in the United States, China, Malaysia, and India. ${ }^{9}$ Demand for plastic goods is closely correlated with GDP growth, with large markets emerging in developing countries, where populations are moving into the middle class. To increase its competitiveness in the sector, Saudi Aramco is investing in technology for direct conversion of crude oil into chemicals, bypassing the refining phase and reducing energy inputs (Brelsford 2018).

Lubricant production is another climate-compliant use for crude oil, since lubricants are (ideally) not combusted. Improvements in lubricant

See: “Oil 2018," International Energy Agency, March 5, 2018. https://www.iea.org/ oil2018/.

${ }^{9}$ Examples include an ethylene plant proposed in Texas in 2017 that would combine investments from SABIC and Exxon Mobil; a Saudi Aramco-Sinopec-ExxonMobil integrated refining and petrochemical plant operating in Fujian, China since 2009. Further, in 2018, Saudi Aramco announced a combined refining-petrochemical venture in India that would link it with three Indian firms; and in Malaysia, the Saudi company announced joint ventures with Petronas, Malaysia's state-owned oil company, for an integrated refinery and petrochemical project in southern Malaysia. 
performance have also decreased fuel consumption by reducing friction and improving the efficiency of machine operations (Boonen and Vanderreydt 2017). As with plastics, lubricating oil can be recycled, which improves environmental efficiency, but reduces growth prospects of the market.

\subsection{Differentiating Among Crude Oil Grades by Carbon Intensity}

Saudi Arabia and other big Middle East oil producers have long enjoyed low average costs of producing their oil reserves, in comparison with other oil producing states. Now it turns out that low-cost producers like Saudi Arabia enjoy a related advantage: crude oil with low carbon intensity.

That is because cost of production is partly based on the energy expended in lifting crude oil from the reservoir to the surface, and in processing and transporting it. Lifting costs are lowest in reservoirs with low water content and high levels of natural drive pressure, requiring minimal use of energy-intensive recovery techniques such as steam flooding (Masnadi et al. 2018, 220).

A further factor affecting carbon intensity of oil production relates to the flaring of natural gas produced in association with crude oil. Flaringor burning off gas at the wellhead-releases even more $\mathrm{CO}_{2}$ into the atmosphere. Saudi Arabia and some of its neighbors, such as the UAE, Qatar, and Kuwait, flare very little natural gas, preferring to capture the gas for domestic use. Other producers like Russia, Iran, Iraq, and the United States flare enormous amounts of gas, exacerbating the carbon footprint of their crude oil (Fig. 12.4). ${ }^{10}$

Altogether, producing, transporting, and refining crude oil accounts for $15 \%$ to $40 \%$ of the entire lifecycle GHG emissions-including final combustion - of oil-based transport fuels. Among major producers, crude oil from Saudi Arabia exhibits the lowest carbon intensity. Other relatively low-carbon oil is produced by Ghana, Norway, Azerbaijan, and Kuwait. At the high end of the scale is ultra-heavy crude from Canada's oil sands and

\footnotetext{
${ }^{10}$ Russia was No. 1 in flaring in 2016, followed by Iraq, Iran, Venezuela, Algeria, and the United States. Big oil producers in the Persian Gulf flared much smaller amounts. Saudi Arabia was No. 13, Kuwait was No. 25, Qatar was No. 28, and the UAE was in 31st place, with less gas flared than even minor oil producing countries such as the United Kingdom and Vietnam. See: World Bank, "Global Gas Flaring Reduction Partnership (GGFR): Upstream Gas Flaring;" http://www.worldbank.org/en/programs/gasflaringreduction\#7.
} 


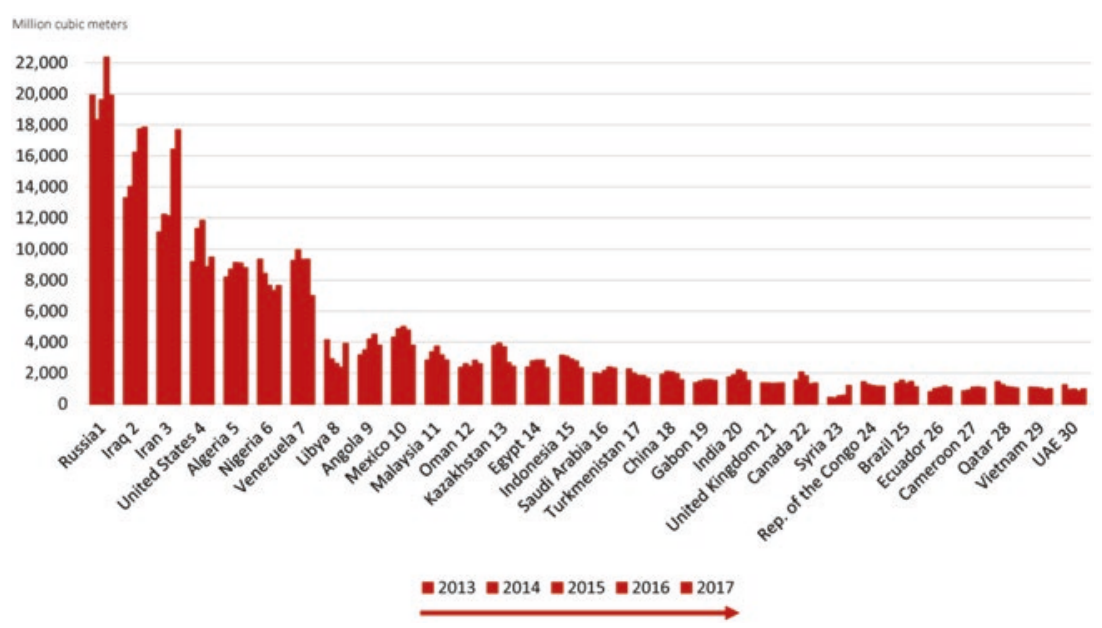

Fig. 12.4 Top 30 flaring countries. (Source: NOAA/GGFR)

Venezuela's Orinoco Belt, where energy-intensive steam flooding is used to increase viscosity of crude oil that, in its natural state, appears closer to a solid (Masnadi et al. 2018).

Given such a timely environmental advantage, Saudi Aramco will begin highlighting the low carbon intensity of its crude oil as a marketing strategy (Interview with Saudi oil official, Feb. 13, 2018). Low carbon intensity could even translate into a price advantage in countries that levy carbon taxes, if carbon taxes were designed to differentiate among crude grades by carbon intensity. More typically, carbon taxes apply an average value to oil products irrespective of origin.

As Table 12.2 shows, Saudi medium crude priced at $\$ 70 /$ barrel with a $\$ 25 /$ ton carbon tax would cost $\$ 81.64$ per barrel. A barrel of Venezuelan Orinoco crude would be priced at $\$ 85.98$, a $\$ 4.34$ premium. At a $\$ 50$ carbon tax, the effect would be magnified. The Saudi barrel would be nearly $\$ 9$ cheaper, at $\$ 93.29$, versus $\$ 101.97$ for the Orinoco.

\subsection{Backing Internal Combustion Engines over EVs}

The kingdom also plans strategic investments to prolong the use of gasoline in transportation, by maximizing the efficiency of the internal combustion engine, so that oil-fueled transportation remains cost-competitive 
Table 12.2 Carbon taxes on Saudi and Venezuelan crudes at $\$ 70$ per barrel

\begin{tabular}{|c|c|c|c|c|c|c|c|}
\hline $\begin{array}{l}\text { Crude oil } \\
\text { source }\end{array}$ & $\begin{array}{c}\text { Upstream } \\
\text { GHG } \\
\text { intensity } \\
\left(g \mathrm{CO}_{2} \text { eq/ }\right. \\
\mathrm{MJ})\end{array}$ & $\begin{array}{c}\text { Upstream } \\
\text { GHG tax } \\
\text { per barrel } \\
\text { @ } \$ 25 \\
\text { tonne }\end{array}$ & $\begin{array}{c}\text { Upstream } \\
\text { GHG tax } \\
\text { per barrel } \\
\text { @ } \$ 50 \\
\text { tonne }\end{array}$ & $\begin{array}{c}\text { Total } \\
\text { GHG } \\
\text { tax } \\
@ \$ 25 \\
\text { tonne* }\end{array}$ & $\begin{array}{c}\text { Total } \\
\text { GHG } \\
\text { tax } \\
@ \$ 50 \\
\text { tonne }\end{array}$ & $\begin{array}{c}\text { Oil price } \\
@ \$ 70 \\
b b l+\$ 25 \\
\text { tax }\end{array}$ & $\begin{array}{c}\text { Oil price } \\
@ \$ 70 \\
b b l+\$ 50 \\
\operatorname{tax}\end{array}$ \\
\hline $\begin{array}{l}\text { Saudi } \\
\text { average }\end{array}$ & 3.5 & $\$ 0.54$ & $\$ 1.07$ & $\$ 11.64$ & $\$ 23.28$ & $\$ 81.64$ & $\$ 93.28$ \\
\hline $\begin{array}{l}\text { Venezuela } \\
\text { Orinoco }\end{array}$ & 31.9 & $\$ 4.88$ & $\$ 9.76$ & $\$ 15.98$ & $\$ 31.97$ & $\$ 85.98$ & $\$ 101.97$ \\
\hline
\end{tabular}

Source: Baker Institute using $\mathrm{CO}_{2}$ intensities from Masnadi et al. (2018)

*Includes upstream $\mathrm{CO}_{2}$ emissions as well as those from transport, refining and final combustion; Venezuelan heavy crude oil typically sells at a discount to more valuable lighter grades, a distinction that is not captured in these figures

with electric vehicles. From the Saudi perspective, an efficient hybrid vehicle is preferable to an all-electric vehicle that uses no petroleum. Saudi Aramco touted its vehicle research-and the "unparalleled energy density of hydrocarbons" - at the North American International Auto Show in Detroit in 2018. On display were high-efficiency gasoline compression ignition engines as well as a car with on-board carbon capture and storage capability (Interviews with Saudi Aramco, Feb. 13, 2018). ${ }^{11}$ In August 2018, Saudi Aramco announced it would cooperate with Japanese auto manufacturer Mazda to develop more efficient engines and gasoline that would reduce GHG emissions from the transport sector (Saudi Aramco 2018). These developments would improve petroleum's competitiveness versus alternative fuels and technologies.

\subsection{The 'Lock In' Strategy}

A subset of the "Dig In" strategy is the "Lock In" approach, where NOCs purchase oil and gas infrastructure inside importing countries. Refineries have been the main target, and Saudi Aramco the largest proponent.

Aramco has created joint ventures that provide influence or even control over the refinery configuration and, by extension, the supply of crude

\footnotetext{
${ }^{11}$ See also: "Aramco showcases flagship technologies at Detroit auto show," Saudi Aramco press release, Jan. 31, 2018. http://www.saudiaramco.com/en/home/news-media/news/ flagship-technologies-detroit-auto-show.html.
} 
oil to the refinery process. Aramco has bought stakes in refineries in China, ${ }^{12}$ South Korea (S-Oil n.d.), Japan (Showa Shell Sekiyu K.K. 2016), and the United States (Gramer 2017) and was in the process of negotiating further purchases in India (El Gamal 2018) and Malaysia (Lee and Cheong 2018). Similarly, the Kuwait Petroleum Co. has purchased a 35\% ownership and operational stake in a refinery in Vietnam configured around Kuwaiti crude ( $\mathrm{Vu} 2018$ ).

At times, when oil markets are in oversupply-perhaps due to weakening demand amid a transition to cleaner energy-Saudi Aramco can ensure that Saudi crudes have preferential access to Saudi-owned refineries (Krane 2015a, 99-104). The tactic is reminiscent of that adopted in the early twentieth century by the Seven Sisters cartel, which controlled market entry through integrated ownership of upstream, midstream, and downstream infrastructure. Other states, which lack the "integration" pursued by Aramco could find ready markets lacking.

\section{Strategy No. 2 “Join In” Climate Action}

For now, climate change in producer states is primarily seen as an indirect threat to demand for oil and gas. But producer countries are also vulnerable to the direct threat of climate change, and to the multilateral call to "join in" the campaign against global warming. As international resolve has coalesced around the desirability of GHG mitigation, the Saudi climate negotiating stance has grown more accepting of the scientific consensus and the need for action. The 2015 Paris Agreement saw Saudi Arabia and its neighbors declaring nationally determined contributions (NDCs) to reduce emissions of GHGs.

Notwithstanding the backtracking described above, Saudi Arabia has, at least in public, shifted its stance to one of support for climate action.

\footnotetext{
${ }^{12}$ Aramco owns a share of the Fujian Refining \& Petrochemical Co. (company website, http://www.frep.cn/en/view-category?categoryId=ff800808129f00d8e0129f00d $94 \mathrm{e} 31100)$ and is in the process of purchasing stakes in two more, as well as entering longterm supply contract with a private Chinese refiner. See: Rania El Gamal, "Saudi Aramco eyes partnerships as it expands refining, petrochems." Reuters, June 12, 2018; https://www. reuters.com/article/us-saudi-aramco-downstream-exclusive/exclusive-saudi-aramco-eyespartnerships-as-it-expands-refining-petrochems-idUSKBN1J81M9; See also: "New Private Chinese Refinery In Talks For Long-Term Saudi Oil Supplies," Oilprice.com, May 31, 2018; https://oilprice.com/Latest-Energy-News/World-News/New-Private-Chinese-RefineryIn-Talks-For-Long-Term-Saudi-Oil-Supplies.html.
} 
Energy minister Khalid Al-Falih issued a statement in support of the 2016 Congress of Parties (COP) 22 in Marrakesh. "We view the Paris Agreement as balanced and fair, and this will pave the way to effective implementation in addressing our climate goals and sustainable development goals holistically," al-Falih said. "It is encouraging to note that the Paris Agreement has achieved the threshold for entry into force, and Saudi Arabia is determined to see it implemented." (Ministry of Energy, Industry \& Mineral Resources of Saudi Arabia 2017)

The revised Saudi posture accepts the necessity of reducing GHG emissions, but in a selective way. Domestically, the kingdom has launched two reforms of fossil fuel subsidies, raising prices and reducing demand for transport fuels, electricity, and desalinated water. These reforms have economically rational goals of reducing government spending on energy provision and decreasing the "cannibalism" of exportable energy commodities. But they serve double-duty as environmental policy, since they also reduce growth in the kingdom's GHG emissions.

Internationally, Saudi Arabia promotes an altogether different strategy, featuring efforts that protect the interests of oil-exporting states in ways that do not harm demand for fossil fuels. Supported strategies include:

- Carbon capture and storage (CCS): CCS involves capturing carbon emissions after combustion and storing them permanently underground. CCS technology has progressed slowly, and adoption has been undermined by expense and inefficiency, and the slow uptake in carbon pricing required to spur adoption. CCS actually increases fossil fuel input for the same energy output because capturing and compressing $\mathrm{CO}_{2}$ requires combusting additional fuel. Saudi Arabia and the UAE are members of the Carbon Sequestration Leadership Forum, and the kingdom has pledged to capture and use $\mathrm{CO}_{2}$ in various applications, including in petrochemical production and EOR.

- Flaring reductions: As mentioned, Saudi Arabia has succeeded in curtailing wasteful flaring of natural gas, but other countriesincluding the United States-have been less successful. Altogether, $3.5 \%$ of global gas consumption, or 149 billion cubic meters-more than Japan's entire 2017 consumption-is burned as waste (World Bank n.d.). Many fossil fuel proponents acknowledge that "cleaning up" the sector itself would reduce pressure to curtail final consumption. 
- Focus on "alternate" GHGs: Saudi officials want more attention paid to GHGs, such as methane and nitrous oxides, which, although forming a smaller portion of overall emissions, carry much higher heat-trapping properties than $\mathrm{CO}_{2}$. Nitrous oxides are largely used in fertilizers in the agricultural sector. Most methane pollution flows from leaks in upstream oil and gas infrastructure. Saudi Arabia has championed the Global Methane Initiative to reduce fugitive methane emissions (Global Methane Initiative n.d.).

The Saudi COP 22 brief also argues that fossil fuels should be retained in a future energy mix due to their synergies with renewables. The kingdom sees $\mathrm{CO}_{2}$ emissions as a "harmful side effect" that can be mitigated with technological solutions (Ministry of Energy, Industry \& Mineral Resources of Saudi Arabia 2017). In 2014, Saudi Aramco joined the Oil and Gas Climate Initiative, a group of 13 major oil companies each pledging \$100 million for research into low-emissions fossil fuel technology.

\subsection{Renewables and Nuclear Power}

The Saudi climate approach also leans on aspirations for replacing oil-fired power generation with zero-carbon renewable and nuclear electricity generation within the kingdom. There are strong economic rationales for policies that push oil out of the Saudi power generation sector, given oil's international market value and the very low cost of solar power in a country with world-leading insolation and plenty of empty land. But, as of mid-2018, neither nuclear nor renewable generation had an appreciable presence in the kingdom. In 2017, Saudi Arabia produced just $0.04 \%$ of its electricity-135 gigawatt-hours of a total of nearly 376,000 GWhsfrom solar means, the only non-hydrocarbon source of electricity currently online in the country (BP 2018). Instead, a rising share of the Saudi power market was being claimed by natural gas (Table 12.3).

Table 12.3 Power generation by source in KSA

\begin{tabular}{ll}
\hline KSA power generation 2017 & \\
\hline Natural gas & $59 \%$ \\
Oil-based fuels & $41 \%$ \\
Renewables (solar) & $0.04 \%$
\end{tabular}

Source: ECRA (2017) and BP (2018) 


\subsection{Social License to Operate}

In coming years, the kingdom and Saudi Aramco appear likely to highlight these efforts, as well as the low carbon-intensity of its crude, lack of flaring and fugitive methane, and its investments in high-efficiency engines to claim credentials as an "environmentally responsible" supplier of necessary fossil fuels. The business associations it has supported around these issues may in future set minimum compliance standards and issue "green" certifications or endorsements for fuels that meet standards.

Oil's lack of substitutes in the transportation sector, particularly the aviation market, means that these sectors are unlikely to be decarbonized for decades. Oil-based fuels will be necessary far into a climate-constrained energy future. Attention will necessarily turn to the GHG footprints of the various grades of crude in the global oil supply. Suppliers that minimize $\mathrm{CO}_{2}$ and GHG emissions from their upstream, midstream, and downstream supply chains will gain competitive advantage, allowing consumers, refiners, and importing states to differentiate among "clean" and "dirty" oil-based fuels.

Saudi Arabia is positioning itself to present a strong case as a "climate friendly" fuel supplier. As such, the social acceptability of Saudi crude oil is more than a "Join In" in climate action strategy. It also becomes a "Dig In" strategy, since it might also extend the longevity of Saudi supply in the global oil market - and the social stability in a kingdom where politics are structured around oil rents.

\section{Strategy No. 3 “Throw In" AND ACCEPT Climate Damage}

Finally, there is the "Throw In" strategy, a collective approach whereby producer governments lobby for a relaxation of the atmospheric GHG accumulation limit of 450 parts per million of $\mathrm{CO}_{2}$ equivalent. This is the maximum GHG concentration associated with limiting the global average temperature increase to $2{ }^{\circ} \mathrm{C}$, which forms the basis for the Paris agreement.

As an alternative, fossil fuel producers, scholars, and others have been developing a relaxed climate strategy they describe as a more "pragmatic" path toward decarbonizing global energy systems. The strategy amounts 
to a concession (i.e. "throwing in the towel") that costs of compliance with $2{ }^{\circ} \mathrm{C}$ emissions limits are unreasonably high, and that more climate damage would be preferable to the economic disruption implied by thoroughgoing and rapid decarbonization. ${ }^{13}$

Among the institutions developing the strategy are Saudi Arabia's Ministry of Energy, Industry and Mineral Resources; Japan's Ministry of Economy, Trade and Industry; as well as the U.S. Chamber of Commerce, the European Union and African Union, and academics from think tanks and universities. At the time of writing, no official document had been released. ${ }^{14}$

The "pragmatic" climate strategy stresses the deficiencies of fossil fuel substitutes and how these energy sources have failed to gain traction in the developing world, where much power demand growth continues to be met by fossil fuels, mainly coal. The narrative points out that climate policy must become cost-competitive for developing countries, and that market mechanisms are needed to motivate advances in technology. It repeats well-known arguments that renewables and electric vehicles are disadvantaged by price, energy density, and intermittency. Therefore, tradeoffs are needed among the three categories of climate spending:

- Adaptation: Investments and engineering techniques that reduce exposure to geographic and climatic changes

- Mitigation: Reducing emissions, including by reducing fossil fuel use

- Damage: Economic losses from climate change.

Most of the tradeoffs lie in the mitigation-versus-damage balance. If strict mitigation measures are imposed before substitute technology is mature, proponents of the strategy argue that costs of mitigation could outweigh the costs of damage and adaptation, resulting in a larger-thanoptimal expense. In Fig. 12.5, Path 3 represents an "unbalanced" climate policy dominated by mitigation.

\footnotetext{
${ }^{13}$ These strategies are outlined in Samantha Gross and Yuhji Matsuo, "Towards More Pragmatic Global Climate Goals and Policies," scholarly paper (Riyadh: KAPSARC, October 2017), http://eneken.ieej.or.jp/data/7608.pdf. Also see slides 17-20 in: Yukari Yamashita, "Climate Change and Economic Growth in Asia: What Are Realistic Goals?" (Powerpoint presentation, March 16, 2017), https://www.bakerinstitute.org/media/files/ files/0587096b/Pragmatic_Approach_Baker_Institute_yamashita.pdf.

${ }^{14}$ In the interest of full disclosure, the author declares his involvement in the process.
} 


\section{Rule for ultra long-term: Reduce the total cost}

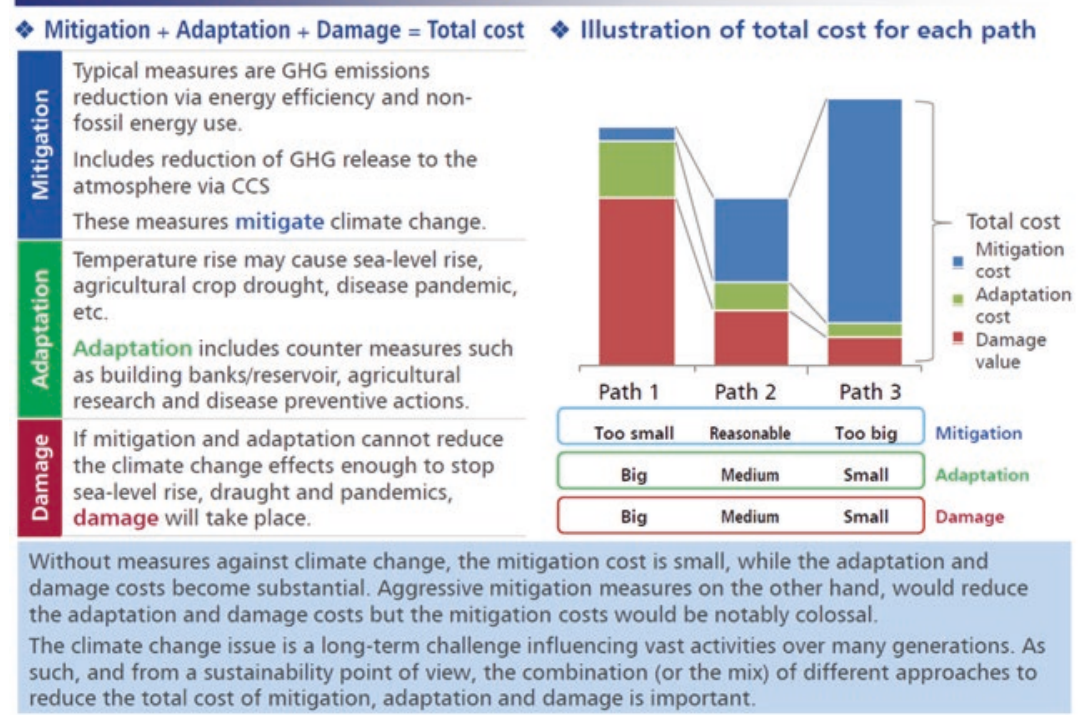

Fig. 12.5 Comparison of cost paths with varying levels of spending on mitigation, adaptation, and damage. (Source: Institute for Energy Economics)

However, the pragmatists' "optimum” path (Path 2 in Fig. 12.5), which minimizes total cost, provides insufficient decarbonization to meet the $2{ }^{\circ} \mathrm{C}$ carbon target. Average warming might reach $3{ }^{\circ} \mathrm{C}$ and bring catastrophic climate damage. But the costs of widespread damage wouldproponents argue-be more than offset by reductions in spending on mitigation. This finding also implies less harm to fossil fuel producers and to developing economies seeking low-cost energy services.

These raw estimates raise questions in regards to the accounting methods used, which are based on modeling carbon taxes required to bring about sufficient reductions in demand. A very rough comparison of actual climate mitigation and damage costs highlights potential weaknesses in the assumptions. For instance, between 1980 and 2018, the United States sustained some $\$ 1.5$ trillion in damage from 219 weather and climate disasters (Smith 2018). The portion of those damages attributed to climate change is unknown. By contrast, the US government spent a tenth 
of that amount, less than $\$ 150$ billion, between 1993 and 2014 (a shorter period) on climate research, technology, and assistance (US Government Accountability Office n.d.).

More specifically, in 2017, the United States experienced a record \$306 billion in damages from weather and climate disasters (Fig. 12.6). That amount is five times the 2017 revenues of Saudi Aramco ${ }^{15}$ and more than $70 \%$ of OPEC's 2016 oil export revenues. ${ }^{16}$ If anthropogenic climate factors were responsible for $20 \%$ of the damage-due to intensified droughtinduced wildfires and flooding from extreme rainfall-paying for that

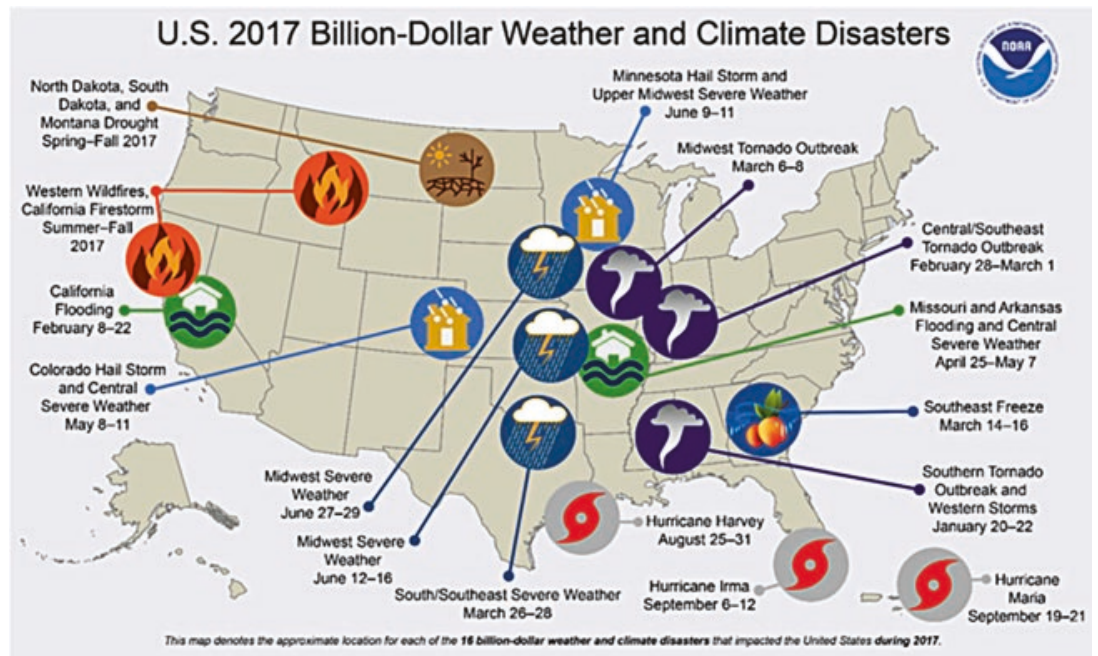

Fig. 12.6 US 2017 billion-dollar weather and climate disasters. (Source: NOAA)

${ }^{15}$ The Saudi Aramco revenues estimate comes from a rough doubling of Saudi Aramco reported revenues of $\$ 33.8$ billion in the first half of 2017. See: "The Aramco Accounts: Inside the World's Most Profitable Company," Bloomberg News. April 13, 2018 (https:// www.bloomberg.com/news/articles/2018-04-13/the-aramco-accounts-inside-the-worlds-most-profitable-company). The US climate-related weather damages come from: Adam B. Smith "2017 U.S. billion-dollar weather and climate disasters: a historic year in context," Climate.gov; Jan. 8, 2018. (https://www.climate.gov/news-features/blogs/ beyond-data/2017-us-billion-dollar-weather-and-climate-disasters-historic-year).

${ }^{16}$ The 13 OPEC member states earned a combined $\$ 433$ billion in 2016. See: "OPEC Revenues Fact Sheet," US Energy Information Administration, May 15, 2017. https:// www.eia.gov/beta/international/regions-topics.php?RegionTopicID=OPEC. 
portion alone would require Saudi Aramco's entire 2017 revenues. Of course, $20 \%$ may be too large an estimate of the anthropogenic role, but the damages tallied are also incomplete and do not account for heatrelated mortality, decreased crop yield, increased electricity demand, and other factors such as negative feedback loops from shrinking snow and ice cover, or methane releases from thawing permafrost (Fig. 12.7). ${ }^{17}$

Finally, the 2018 IPCC report estimates global economic damages from $2{ }^{\circ} \mathrm{C}$ warming by 2100 at the nearly unfathomable sum of $\$ 69$ trillion (Intergovernmental Panel on Climate Change n.d.). Tallying the additional damage from a further degree of warming, including changes in coastlines and increased human migration and conflict, threatens to render an already tenuous concept inconceivable. It is hard to envision anything pragmatic about a goal based upon $3{ }^{\circ} \mathrm{C}$ warming, except perhaps in the very short term.

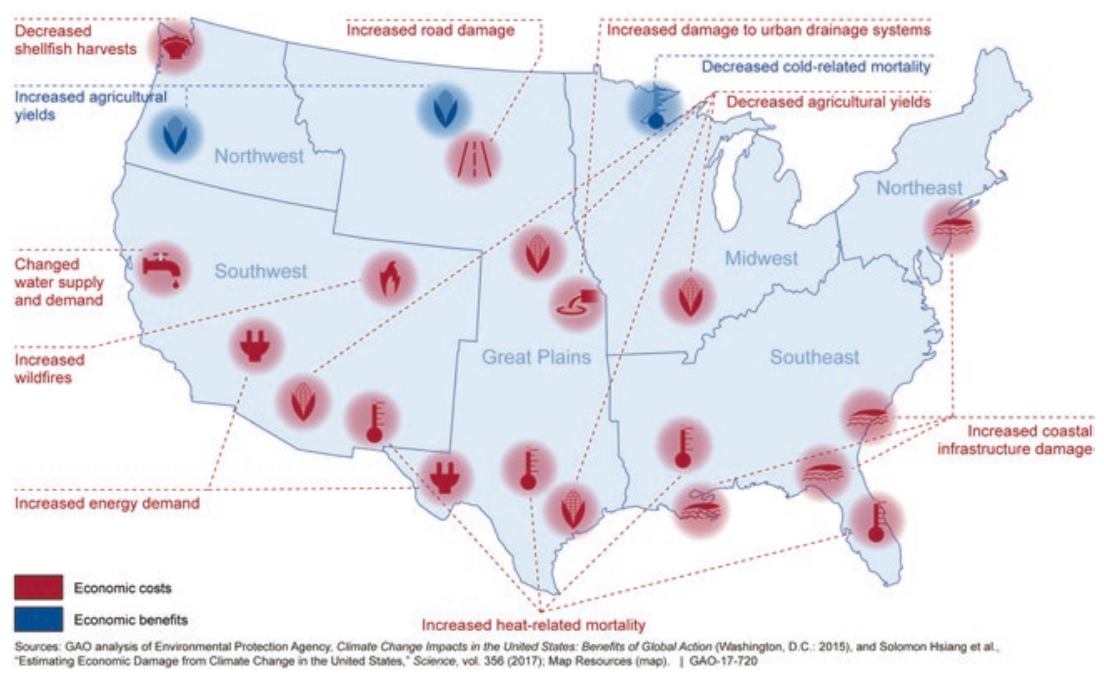

Fig. 12.7 Examples of potential economic effects from climate change by 2100 . (Source: TBD)

${ }^{17}$ It is worth adding that no amount of mitigation spending in 2017 would have affected climate change-related disasters in 2017. Results could only be expected in future years. Effective mitigation requires GHG reductions outside the United States as well. Further, the future "payoff" in tempering climate change could be difficult to measure given natural climate variability, making current spending justifications difficult. 
In summary, the "throw in" strategy revolves around speculation that humanity will be better off by delaying strict mitigation because improved technology will emerge in the future and reduce GHG emissions without terminating the fossil fuel industry. Given that such technologies have neither been demonstrated nor deployed, the "throw in" strategy may be described as a multilateral version of Saudi Arabia's obstructionism approach.

\section{Conclusion: A Fourth Strategy}

The three strategy types above outline near-term practices producer states might adopt to coexist with climate action, seeking not just to survive, but to recast their businesses in ways that provide competitive advantages.

Despite the increasing climate consciousness in Saudi Arabia and its improved relations with the global climate regime, some of the strategies outlined here are best described as alterations in the manner in which fossil fuels harm the Earth's climate, geography, inhabitants, and their property. While improvements in upstream production techniques can assist at the margins, it is worth noting that the fossil fuel sector-oil, gas, and coal-remains responsible for two-thirds of the ongoing GHG emissions that continue to accumulate in the atmosphere. To the extent that strategies outlined here assist producers with marketing fuels that continue to be combusted in unabated fashion, they prolong damage to the Earth's climate, despite providing short-run economic benefits, particularly in developing countries.

A fourth strategy-briefly mentioned in the introduction-offers greater promise than the three above: Diversification beyond the oil and gas business. For companies, particularly shareholder-owned oil companies, diversification is part of the constant challenge of adjusting to evolving markets. When governments nationalized their oil concessions in the 1970s, the big Western oil companies created new opportunities elsewhere. Climate action is hastening the next major shift in the energy business.

For producer countries, nonoil diversification also makes sense. The more prudent of these states have actively begun creating new economic sectors that complement and eventually can replace those facing the risk of climate action. Ironically, a robust fossil fuel export sector is useful in funding investments aimed at diversifying away from fossil fuels. Some oil producers have taken steps in this direction. The United Arab 
Emirates - and Dubai in particular-have built diversified economies that are already unwinding lopsided dependence on oil exports and prices. Saudi Arabia has announced a similar effort. Structural barriers in the GCC labor markets add complexity to diversification.

Perhaps the largest hurdle to diversification is, as mentioned, the continued availability of economic rents that have persisted in the oil business for more than a century. Inevitably, diversification will bring profits that appear disappointing in comparison to the lopsided earnings from lowcost oil.

Regardless, the oil market appears likely to grow more competitive as demand shifts into reverse in the OECD, and developing Asia becomes the main growth focus. How oil producing countries adapt in the long run remains in question.

A more chaotic oil market could be one result. Producers might seek a more bilateral route to marketing of oil, pairing with importers in an environment of enhanced competition. Hydrocarbon states which cannot compete may find themselves sidelined-either for geological (cost) reasons or above-ground political and institutional deficiencies, or even importer embargo.

Alternatively, producer countries could pursue a more cooperative path. One envisions an enhanced role for OPEC in allocating producers with equitable shares of a shrinking global oil market in the best interests of exporters and the global climate. If that happened, OPEC's organizing principle might shift. Rather than managing the price of oil, it might allot member countries a share of the market based not just on a member state's output capacity, but on the climate credentials of the oil it produced. The preparations outlined in Saudi Arabia, the world's low-cost, low-carbon oil producer, would place it in a strong position in either scenario.

\section{REFERENCES}

Boonen, Katrien, and Ive Vanderreydt. 2017. "Evolution of Environmental Impacts and Benefits of Motor Oil from a Lifecycle Perspective." Sept. 12, 2017. http://www.essenscia.be/en/Document/Download/16770.

BP. 2018. "Statistical Review of World Energy 2018." Accessed July 25, 2019. https://www.bp.com/en/global/corporate/energy-economics/statisticalreview-of-world-energy/downloads.html.

Brelsford, Robert. 2018. "Aramco, SABIC let contract for crude oil-to-chemicals complex." Oil and Gas Journal, April 30, 2018. https://www.ogj.com/articles $/ 2018 / 04 /$ aramco-sabic-let-contract-for-crude-oil-to-chemicalscomplex.html. 
Depledge, Joanna. 2008. "Striving for No: Saudi Arabia in the Climate Change Regime." Global Environmental Politics 8, no. 4: 9-35. https://doi. org/10.1162/glep.2008.8.4.9.

El Gamal, Rania. 2018. "Saudi Aramco eyes partnerships as it expands refining, petrochems." Reuters, June 12, 2018. https://www.reuters.com/article/ussaudi-aramco-downstream-exclusive/exclusive-saudi-aramco-eyes-partnershipsas-it-expands-refining-petrochems-idUSKBN1J81M9.

Electricity Co-Generation and Regulatory Authority, "Annual Statistical Booklet for Electricity and Seawater Desalination Industries." Riyadh, ECRA 2017. https://www.ecra.gov.sa/en-us/MediaCenter/DocLib2/Lists / SubCategory_Library/ECRA-Statistical-Booklet-2017.pdf.

Emissions Database for Global Atmospheric Research. 2017. "Fossil CO 2 \& GHG Emissions of All World Countries, 2017." European Commission science database. Accessed July 25, 2019. http://edgar.jrc.ec.europa.eu/overview. php?v=CO2andGHG1970-2016.

Emissions Database for Global Atmospheric Research. 2011. "Global Emissions EDGAR v4.2 (November 2011)," European Commission science database. Accessed July 25, 2019. http://edgar.jrc.ec.europa.eu/overview.php?v=42.

Ezekoye, Obi, Andjelka Milutinovic, and Theo Jan Simons. 2018. 2018, May. "Chemicals and capital markets: Back at the top." McKinsey. https://www. mckinsey.com/industries/chemicals/our-insights/chemicals-and-capitalmarkets-back-at-the-top.

Global Methane Initiative. n.d. "Partner Countries: Saudi Arabia.” Accessed July 25, 2019. https://www.globalmethane.org/partners/country.aspx?country= saudiarabia.

Gramer, Robbie. 2017. "Saudi Arabia Now Controls the Largest Oil Refinery in North America." Foreign Policy, May 3, 2017. https://foreignpolicy. com $/ 2017 / 05 / 03 /$ saudi-arabia-now-controls-the-largest-oilrefinery-in-north-america-energy-middle-east-aramco/.

Intergovernmental Panel on Climate Change. n.d. "Impacts of $1.5^{\circ} \mathrm{C}$ of Global Warming on Natural and Human Systems." p. 264. Accessed July 25, 2019. https://www.ipcc.ch/site/assets/uploads/sites/2/2019/02/SRl5_ Chapter3_Low_Res.pdf.

International Energy Agency. 2018. "The Future of Petrochemicals: Towards More Sustainable Plastics and Fertilisers." https://webstore.iea.org/download/direct/2310?fileName=The_Future_of_Petrochemicals.pdf.

Jackson, RB, C Le Quéré, RM Andrew, JG Canadell, JI Korsbakken, Z Liu, GP Peters, and B Zheng. 2018. "Global Energy Growth Is Outpacing Decarbonization." Environmental Research Letters 13, no. 12: 120401. https://iopscience.iop.org/article/10.1088/1748-9326/aaf303/meta. 
Krane, Jim. 2014. "Stability versus Sustainability: Energy Policy in the Gulf Monarchies." PhD dissertation, University of Cambridge. https://doi. org/10.17863/CAM.5943.

Krane, Jim. 2015a. "A Refined Approach: Saudi Arabia Moves beyond Crude." Energy Policy 82: 99-104. https://doi.org/10.1016/j.enpol.2015.03.008.

Krane, Jim. 2015b. "Rationalizing Energy Demand through End-User Prices in the GCC.” Oxford Energy Forum, no. 102 (November).

Lee, Heesu and Serene Cheong. 2018. "A Saudi-Backed Asia Refinery Is Going to Be a Fuel Juggernaut." Bloomberg, May 17, 2018. https://www.bloomberg. com/news/articles/2018-05-17/fuel-juggernaut-coming-as-saudibacked-asia-refinery-giant-stirs.

Masnadi, Mohammad S, Hassan M El-Houjeiri, Dominik Schunack, Yunpo Li, Samori O Roberts, Steven Przesmitzki, Adam R Brandt, and Michael Wang. 2018. "Well-to-Refinery Emissions and Net-Energy Analysis of China's CrudeOil Supply." Nature Energy 3, no. 3: 220. https://doi.org/10.1038/ s41560-018-0090-7.

Ministry of Energy, Industry \& Mineral Resources of Saudi Arabia. 2017. "Saudi Arabia Takes Its Place as Global Citizen at COP 22." https://docs.wixstatic. com/ugd/bc5fc9_455265c3bb8a4ldb987af3d3f72308cc.pdf.

Pal, Jeremy S., and Elfatih A. B. Eltahir. 2016. "Future Temperature in Southwest Asia Projected to Exceed a Threshold for Human Adaptability." Nature Climate Change 6, no. 2 (February): 197-200. https://www.nature.com/articles/ncl imate 2833? platform=oscar\&draft=journal.

Plumer, Brad and Lisa Friedman. 2018. "Trump Team Pushes Fossil Fuels at Climate Talks. Protests Erupt, but Allies Emerge, Too.” New York Times, Dec. 10, 2018. https://www.nytimes.com/2018/12/10/climate/katowice-climate-talks-cop24.html.

Saudi Aramco. 2018. "Saudi Aramco, Mazda Motor Corporation and AIST collaborate to develop the world's most advanced engine/fuel combination." Aug. 8, 2018. http://www.saudiaramco.com/en/home/news-media/news/ Saudi-Aramco-Mazda-and-AIST-collaborate-on-advanced-engine.html.

Showa Shell Sekiyu K.K. 2016. “Corporate Report 2017.” p. 101. Dec. 31, 2016. https://www.idemitsu.com/content/100866140.pdf.

Smith, Adam B. 2018. "2017 U.S. billion-dollar weather and climate disasters: a historic year in context." NOAA, Jan. 8, 2018. https://www.climate.gov/ news-features/blogs/beyond-data/2017-us-billion-dollar-weatherand-climate-disasters-historic-year.

Smith, James B. 2010. "What Concerns Saudi Arabia about the Future of Energy and Climate Change." Diplomatic cable. Riyadh: US State Department via WikiLeaks, February 21, 2010.

S-Oil. n.d. "History." Accessed July 25, 2019. http://www.s-oil.com/en/company/History.aspx. 
US Government Accountability Office. n.d. "Climate Change Funding and Management." Accessed July 25, 2019. https://www.gao.gov/key_issues/ climate_change_funding_management/issue_summary.

Van de Graaf, Thijs, and Aviel Verbruggen. 2014. "Saving OPEC: How Oil Producers Can Counteract the Global Decline in Demand." Foreign Affairs, December 22, 2014. https://www.foreignaffairs.com/articles/persiangulf/2014-12-22/saving-opec.

Van de Graaf, Thijs, and Aviel Verbruggen. 2015. "The Oil Endgame: Strategies of Oil Exporters in a Carbon-Constrained World," Environmental Science \& Policy 54: 456-62. https://doi.org/10.1016/j.envsci.2015.08.004.

Van de Graaf, Thijs. 2018. "Battling for a Shrinking Market: Oil Producers, the Renewables Revolution, and the Risk of Stranded Assets." In The Geopolitics of Renewables, 97-121. Springer.

Vu, Khanh. 2018. "Vietnam's Second Refinery To Be Fully Operational By Early August." Reuters, June 6, 2018. https://www.rigzone.com/news/wire/ vietnams_second_refinery_to_be_fully_operational_by_early_august-06jun-2018-155842-article.

World Bank. n.d. "Global Gas Flaring Reduction Partnership (GGFR): Upstream Gas Flaring." Accessed July 25, 2019. http://www.worldbank.org/en/programs/gasflaringreduction\#7.

Open Access This chapter is licensed under the terms of the Creative Commons Attribution-NonCommercial-NoDerivatives 4.0 International License (http:// creativecommons.org/licenses/by-nc-nd/4.0/), which permits any noncommercial use, sharing, distribution and reproduction in any medium or format, as long as you give appropriate credit to the original author(s) and the source, provide a link to the Creative Commons licence and indicate if you modified the licensed material. You do not have permission under this license to share adapted material derived from this chapter or parts of it.

The images or other third party material in this chapter are included in the chapter's Creative Commons licence, unless indicated otherwise in a credit line to the material. If material is not included in the chapter's Creative Commons licence and your intended use is not permitted by statutory regulation or exceeds the permitted use, you will need to obtain permission directly from the copyright holder. 